\title{
Impacts of climate change on European hydrology at 1.5, 2 and 3 degrees mean global warming above preindustrial level
}

\author{
Chantal Donnelly ${ }^{1}$ (D) Wouter Greuell ${ }^{2}$. \\ Jafet Andersson $^{1}$ • Dieter Gerten ${ }^{3}$. \\ Giovanna Pisacane $^{4} \cdot$ Philippe Roudier $^{5}$ - Fulco Ludwig ${ }^{1}$
}

Received: 23 September 2016 / Accepted: 10 April 2017 / Published online: 16 May 2017

(C) The Author(s) 2017. This article is an open access publication

\begin{abstract}
Impacts of climate change at 1.5, 2 and $3{ }^{\circ} \mathrm{C}$ mean global warming above preindustrial level are investigated and compared for runoff, discharge and snowpack in Europe. Ensembles of climate projections representing each of the warming levels were assembled to describe the hydro-meteorological climate at $1.5,2$ and $3{ }^{\circ} \mathrm{C}$. These ensembles were then used to force an ensemble of five hydrological models and changes to hydrological indicators were calculated. It is seen that there are clear changes in local impacts on evapotranspiration, mean, low and high runoff and snow water equivalent between a $1.5,2$ and $3{ }^{\circ} \mathrm{C}$ degree warmer world. In a warmer world, the hydrological impacts of climate change are more intense and spatially more extensive. Robust increases in runoff affect the Scandinavian mountains at $1.5{ }^{\circ} \mathrm{C}$, but at $3{ }^{\circ} \mathrm{C}$ extend over most of Norway, Sweden and northern Poland. At $3{ }^{\circ} \mathrm{C}$, Norway is affected by robust changes in all indicators. Decreases in mean annual runoff are seen only in Portugal at $1.5{ }^{\circ} \mathrm{C}$ warming, but at $3{ }^{\circ} \mathrm{C}$ warming, decreases to runoff are seen around the entire Iberian coast, the Balkan Coast and parts of the French coast. In affected parts of Europe, there is a distinct increase in the changes to mean, low and high runoff at $2{ }^{\circ} \mathrm{C}$ compared to $1.5^{\circ} \mathrm{C}$, strengthening the case for mitigation to lower levels of global warming. Between 2 and $3{ }^{\circ} \mathrm{C}$, the changes in low and high runoff levels continue to increase, but the
\end{abstract}

Electronic supplementary material The online version of this article (doi:10.1007/s10584-017-1971-7) contains supplementary material, which is available to authorized users.

Chantal Donnelly

chantal.donnelly@smhi.se

Swedish Meteorological Institute, Norrköping, Sweden

2 Earth System Sciences Group, Wageningen University and Research Centre (WUR), Wageningen, The Netherlands

3 Potsdam Institute for Climate Impact Research, 14412 Potsdam, Germany

4 ENEA, Rome, Italy

5 Agence Française de Développement, Paris, France 
changes to mean runoff are less clear. Changes to discharge in Europe's larger rivers are less distinct due to the lack of homogenous and robust changes across larger river catchments, with the exception of Scandinavia where discharges increase with warming level.

\section{Introduction}

Global warming is expected to cause large-scale changes to the terrestrial water cycle affecting water availability for cities, energy production and agriculture, river navigability, flood risks and more. While impacts of climate change on the water cycle in Europe are well studied (e.g. Jiménez Cisneros et al. 2014), it is less well known what the impacts associated with various levels of global warming will be. Targets for climate change mitigation have been set at levels of global mean temperature (GMT) change relative to preindustrial levels. Prior to the 21st session of the Conference of the Parties (COP21), a goal of $+2{ }^{\circ} \mathrm{C}$ warming globally above preindustrial levels was internationally accepted as the level required to prevent dangerous anthropogenic interference with the system (UNFCCC 2010). However, since the 2015 COP21 Paris agreement, a more ambitious mitigation objective to "Hold the increase in the global average temperature to well below $2{ }^{\circ} \mathrm{C}$ above pre-industrial levels and to pursue efforts to limit the temperature increase to $1.5^{\circ} \mathrm{C}$ " has been proposed (UNFCCC 2015). At the same time, if the current trajectory of greenhouse emissions continues, we could end up with more than $3{ }^{\circ} \mathrm{C}$ GMT rise (Sanford et al. 2014). Hence 1.5, 2 and $3{ }^{\circ} \mathrm{C}$ GMT rise are important milestones, not only for mitigation but also to understand the expected impacts of climate change.

Potential changes to Europe's water resources due to climate change have been assessed in several recent studies (e.g. Van Vliet et al. 2015, Forzieri et al. 2014, Schneider et al. 2013), however with the focus of assessing climate change impacts at fixed periods, for example midor end century. Recent studies have begun to assess climate change (Vautard et al. 2014) and associated water impacts in Europe and beyond (Roudier et al. 2016, Gosling et al. 2016) at specific levels of global warming. This study uses a systematic ensemble approach to investigate three research questions: (1) what are the impacts of a $+1.5,+2$ and $+3{ }^{\circ} \mathrm{C}$ increase in GMT and the associated changes in precipitation and other climate variables on evapotranspiration, runoff, snow and river discharge in Europe? (2) What is the sensitivity of the impacts to the design of the climate ensemble, i.e. the choice of representative concentration pathways (RCP), general circulation models (GCMs) and regional circulation model (RCMs) for a particular warming level? (3) Is there a quantifiable difference between the hydrological impacts at different warming levels?

To do this, we employ an ensemble of 11 climate projections (using 3 RCPs, 4 GCMs and 4 RCMs) used to force 5 pan-European hydrological models (HMs), which were evaluated for their suitability in climate change studies by Greuell et al. (2015). This study extends that by Roudier et al. (2016) - which examined the impacts on hydrological extremes at $2{ }^{\circ} \mathrm{C}$ to include hydrological impacts at the $+1.5^{\circ} \mathrm{C}$ mitigation target and the current trajectory beyond $+3{ }^{\circ} \mathrm{C}$ and impacts on mean conditions and snow. To investigate whether the impacts can be quantitatively separated at different warming levels, we assess, spatially explicitly, whether and to what extent there is an increase in impact with increasing GMT. In this study, we also analyse other hydrological indicators: mean evapotranspiration, mean runoff, mean annual low and high runoff and snow water equivalent. We also include an analysis of the sensitivity of the result to the choice of RCP driving the climate ensemble. 


\section{Methods}

\subsection{Atmospheric forcing}

This study makes use of the latest ensemble of high-resolution climate models from CORDEX (Jacob et al. 2014) which uses an ensemble of GCMs from CMIP5 (Taylor et al. 2012). A subset of 11 projections was chosen to represent the spread from the full CORDEX ensemble using cluster analysis (Moss et al. 2010). They are based on five unique GCM/RCM combinations (four GCMs and four RCMs) and three RCPs (RCP2.6, 4.5 and 8.5), and these were combined in different ensembles for the different warming levels. To drive the hydrological models, the climate projections of precipitation and temperature were bias-corrected to the E-OBS (Haylock et al. 2008) gridded observation database using quantile mapping (Wilcke et al. 2013). Other forcing variables were bias-corrected using WFDEI (Weedon et al. 2014).

The method to define warming thresholds in climate models follows that of Vautard et al. (2014) where scenarios that pass the target warming level are used as snapshots in time representing these levels of warming. This is necessary because sufficient ensembles of climate models stabilising at each of these warming thresholds are not available (unless GCM patterns are scaled so as to reach the same warming levels at the same time, as in Heinke et al. 2013). To assess the impacts of climate change at $1.5,2$ and $3{ }^{\circ} \mathrm{C}$ GMT rise, change is quantified for the 30 -year period centred at the year when each GCM reaches the defined increase in GMT relative to preindustrial levels (1881-1910).

The RCP8.5 runs reach the $+1.5^{\circ} \mathrm{C}$ threshold very early in the twenty-first century when the uncertainty from the initial state of the climate models is still very high, so the ensemble for $+1.5^{\circ} \mathrm{C}$ is made up of the lower emission RCPs: RCP2.6 and RCP4.5. For $+3{ }^{\circ} \mathrm{C}$, it is mostly only the RCP8.5 runs that reach $+3{ }^{\circ} \mathrm{C}$ by the end of the century so the ensemble for $+3{ }^{\circ} \mathrm{C}$ is made up of the RCP8.5 (high-emission) runs (Table 1). For $+2{ }^{\circ} \mathrm{C}$, the impacts were calculated twice: (a) for an ensemble of the low-emission RCPs and (b) for an ensemble of the highemission RCP. This is done so that the sensitivity of the impacts to the choice of RCP forcing the ensemble can be studied.

Table 1 Summary of the 11 climate projections used in this study and which warming levels they were used for (period in italics was not used for the corresponding warming level)

\begin{tabular}{llllll}
\hline RCP & Driving GCM & RCM & $+1.5{ }^{\circ} \mathrm{C}$ period & $+2{ }^{\circ} \mathrm{C}$ period & $+3{ }^{\circ} \mathrm{C}$ period \\
\hline 2.6 & MPI-ESM-LR & CSC-Remo & $2035-2064$ & $2071-2100$ & $n a$ \\
2.6 & EC-EARTH & SMHI-RCA4 & $2028-2057$ & $2071-2100$ & $n a$ \\
4.5 & MPI-ESM-LR & CSC-Remo & $2020-2049$ & $2050-2079$ & $n a$ \\
4.5 & EC-EARTH & SMHI-RCA4 & $2019-2048$ & $2042-2071$ & $n a$ \\
4.5 & EC-EARTH & KNMI-RACMO22E & $2018-2047$ & $2042-2071$ & $n a$ \\
4.5 & Had-GEM-ES & SMHI-RCA4 & $2007-2036$ & $2023-2053$ & $2055-2084$ \\
4.5 & IPSL-CM5A-MR & IPSL-WRF331F & $2009-2038$ & $2028-2057$ & $2053-2082$ \\
8.5 & MPI-ESM-LR & CSC-Remo & $2014-2043$ & $2030-2059$ & $2053-2082$ \\
8.5 & EC-EARTH & SMHI-RCA4 & $2012-2041$ & $2027-2056$ & $2052-2081$ \\
8.5 & EC-EARTH & KNMI-RACMO22E & $2012-2041$ & $2028-2057$ & $2052-2081$ \\
8.5 & Had-GEM-ES & SMHI-RCA4 & $2004-2033$ & $2016-2045$ & $2037-2066$ \\
\hline
\end{tabular}




\subsection{Hydrological models}

To account for uncertainties in simulation of hydrological processes, five HMs were systematically used to simulate the impacts of climate change. The chosen HMs differ in complexity of process description, resolution, input data and level of calibration (see S1 for further information on the HMs and how they are parameterised, also Greuell et al. 2015) but were all forced with the same data and produced the same output variables. They include model concepts varying from land-surface schemes (VIC, Liang et al. 1994), to varying levels of process-based hydrological modelling (LISFLOOD, Burek et al. 2013; WBM, Vörösmarty et al. 2000; and E-HYPE, Donnelly et al. 2016) and a coupled water and carbon cycle model with vegetation dynamics (LPJmL, Schaphoff et al. 2013). Methods to simulate evapotranspiration and snow processes vary with each model, e.g. both energy balance and degree day methods are used. Despite these differences, each of the models has demonstrated ability to simulate hydrologic conditions at large scale across Europe (Nijssen et al. 2001; Burek et al. 2013, Donnelly et al. 2016, Biemans et al. 2009) and Greuell et al. (2015) showed that the models showed an ability to respond to differences in wet and dry and warm and cold years (interannual variability). This was postulated as a measure of how HMs might respond to climate change as it was shown that the magnitude of the interannual variability was of a similar order to the expected mean climatic changes (Greuell et al. 2015).

The E-HYPE, Lisflood, WBM and LPJmL models were run on a daily time-step, while VIC was run on a three hourly time-step with results aggregated to daily time-step for the model ensemble. The original HM resolutions vary from $5 \mathrm{~km}$ to $0.5^{\circ}$ (ca.56 $\times 56 \mathrm{~km}$ at the equator, $28 \times 56 \mathrm{~km}$ at $60^{\circ} \mathrm{N}$ ) grid resolution, and in the case of E-HYPE a high-resolution subbasin rather than grid scale, so all model results were post-processed to a common $0.5^{\circ}$ grid before calculation of ensemble results.

\subsection{Hydrological indicators}

Here, the changes to a number of simple indicators, indicative of the climatic development of aspects of the water cycle relevant for user sectors, were quantified. From this, potential impacts that the different warming levels might have on water-related sectors can be inferred. The following hydrological indicators were calculated for all of Europe:

1. Evapotranspiration: Mean annual evapotranspiration

2. Runoff: Mean annual runoff (indicative of available water resources, e.g. for agriculture, water supply, navigation, etc.).

3. High runoff: Mean annual maximum runoff (indicative of recurring high flows)

4. Low runoff: Mean annual low runoff (mean of annual 10th percentile runoff, indicative of dry conditions)

5. Snowpack: Mean annual snow water equivalent (SWE) maximum (indicative of snow storage for hydropower production and tourism)

Runoff, rather than discharge, is analysed due to the different HM resolutions. In total, 55 model runs are analysed, i.e. 11 climate projections and $5 \mathrm{HMs}$. Changes to the indicators are calculated by taking the mean indicator value over the 30 -year periods representing each warming level in each GCM and comparing this to the mean indicator value over the reference period, 1971-2000. So while the warming levels of $+1.5,2$ and $3{ }^{\circ} \mathrm{C}$ are defined relative to 
preindustrial levels, the impacts of the change are analysed relative to a more recent historical period. As well as considering changes to runoff and snow across Europe, changes to discharge from six major European rivers were analysed. To do this, the outlet point of each river was identified separately for each HM. These rivers were chosen to demonstrate the needs for adaptation for navigability (e.g. Rhine, Danube, Wisla), irrigation (Ebro), water supply (Ebro, Wisla), ecology (e.g. Ebro delta), hydropower (Glomma, Lule) and cooling water supply (Wisla).

The differences in impacts between warming levels were compared by plotting the ensemble mean changes at one warming level (e.g. $1.5^{\circ} \mathrm{C}$ ) versus those at another $\left(\right.$ e.g. $2{ }^{\circ} \mathrm{C}$ ) for each grid point. These scatter plots were summarised into box-plots by dividing the $x$-axis into 30 equal size bins and showing the interquartile range in the $y$-direction for each bin. This was done to help with visual interpretation of the plots (original scatter plots available in online supplementary material). A line-of-best-fit, forced through the origin, was fitted to the median values of each bin; a line steeper than the 1:1 line indicates increasing impacts with increasing warming level. A correlation coefficient, $R$, is used to indicate the uniformity of the changes (scalability) across the grid; a value of 1 indicates perfect scalability of the changes across the grid.

\subsection{Assessing reliability of results}

Projected changes are assumed robust where the absolute value of the ensemble mean change exceeds the standard deviation (SD) of the changes of the individual members of the ensemble. Robust changes are stippled in the maps. This is consistent with the method used in the Fourth IPCC Assessment Report by Working Group I (Meehl et al. 2007).

As well as the boxed scatter plots to compare warming levels, similar plots were also made for the two different $2{ }^{\circ} \mathrm{C}$ ensembles to investigate the sensitivity of the method to the choice of RCP forcing in the climate model ensemble. Finally, the slope of the scaling relationship from the scatter plots is compared for each HM to show the variations in HM sensitivity.

\section{Results}

Summarised across Europe, there are quantifiable differences between the impacts for different warming levels for most variables (Fig. 1). This is indicated by the slope of the fitted line of the scatter plots. For precipitation and evapotranspiration, the changes are greater at each subsequent warming level, e.g. where precipitation is projected to decrease with increased warming, these decreases become larger. Similarly projected increases in precipitation become higher. Changes to low runoff and snowpack also increase with each warming level. For mean annual runoff, changes at $2{ }^{\circ} \mathrm{C}$ are greater than at $1.5^{\circ} \mathrm{C}$, but differences are less discernible between 2 and $3{ }^{\circ} \mathrm{C}$ (with the exception of projected large decreases in runoff). For high runoff, the changes at $3{ }^{\circ} \mathrm{C}$ are greater than those at $2{ }^{\circ} \mathrm{C}$, but less discernible for 2 vs $1.5{ }^{\circ} \mathrm{C}$. Spatial uniformity of these relationships across Europe is indicated by small spread, i.e. high $R$ values, and is high for the indicators and warming levels shown here $(R$ values are $>0.9)$ except for runoff which is less uniform $(R=0.856)$.

Some of the uncertainty related to representativeness of the $\mathrm{CM}$ ensemble is assessed by comparing the high and low RCP ensembles for $2{ }^{\circ} \mathrm{C}$ (also Fig. 3). Here we see that although there are differences between these results (i.e. deviation from the 1:1 line) and with slightly 
Annual mean change in precip for lower RCPs

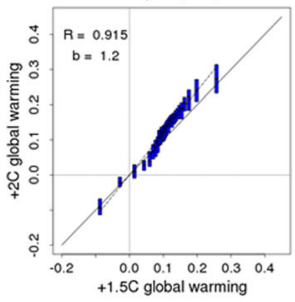

Annual mean change in evap for lower RCPs

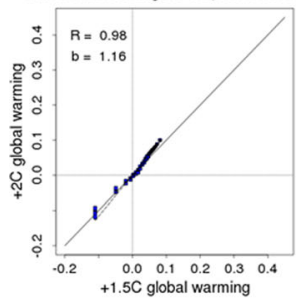

Annual mean change in runoff for lower RCPs

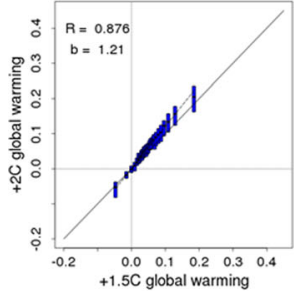

Change in annual max runoff for lower RCPs
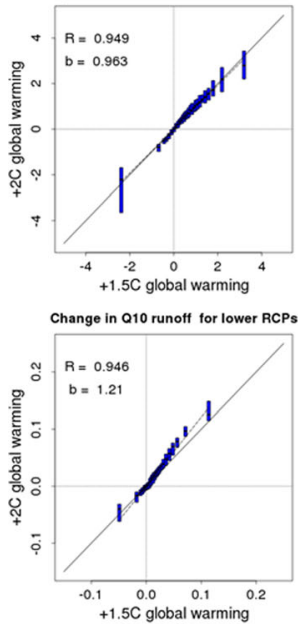

Change in annual max swe for lower RCPs

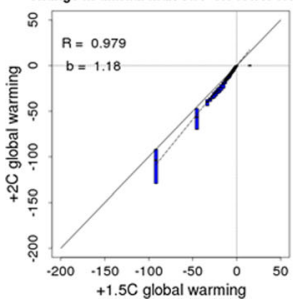

Annual mean change in precip at $+2 \mathrm{C}$ warming

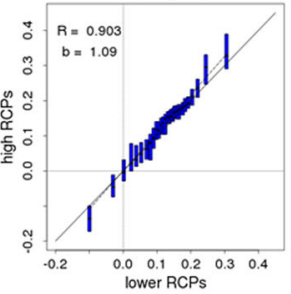

Annual mean change in evap at $+2 \mathrm{C}$ warming

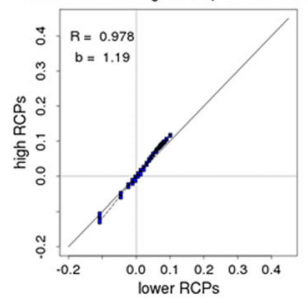

Annual mean change in runoff at $+2 \mathrm{C}$ warming

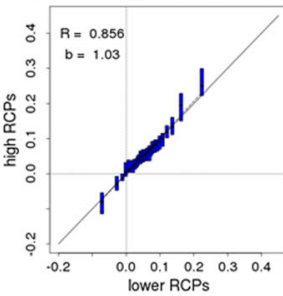

Change in annual max runoff at $+2 \mathrm{C}$ warming

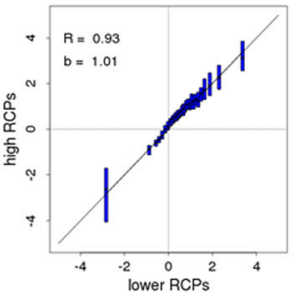

Change in 010 runoff at $+2 \mathrm{C}$ warming

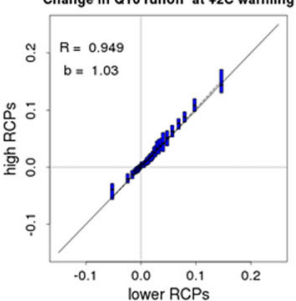

Change in annual max swe at $+2 \mathrm{C}$ warming

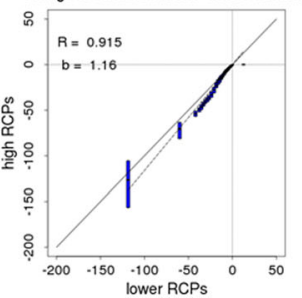

Annual mean change in precip for RCP8.5s

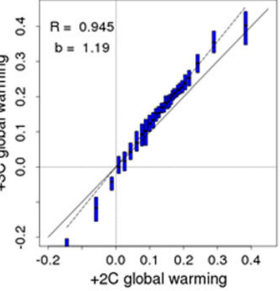

Annual mean change in evap for RCP8.5s

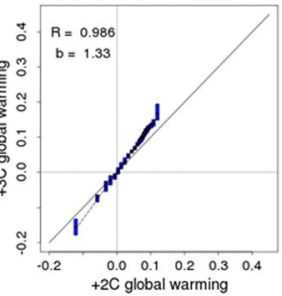

Annual mean change in runoff for RCP8.5s

:. $R=0.879$

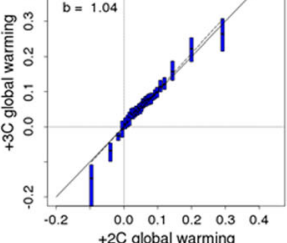

Change in annual max runoff for RCP8.5s
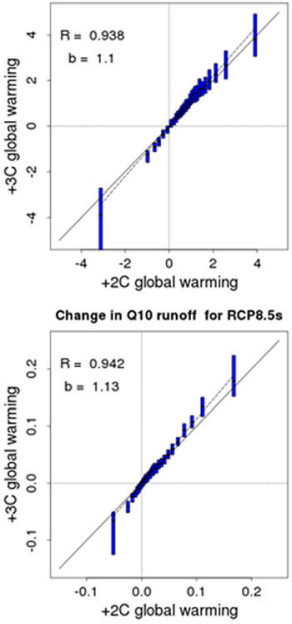

Change in annual max swe for RCP8.5s

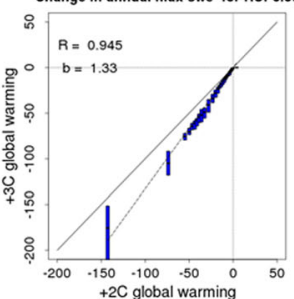


Fig. 1 Comparison of ensemble mean changes in hydrological indicators at different levels of global warming (left and right columns) and for different RCPs (middle column) for $+2{ }^{\circ} \mathrm{C}$. Changes are relative to the baseline period. The plots are based on scatter plots (see supplementary material) of ensemble mean change plotted for each modelled grid cell. The points have been discretised into 30 equal bins (boxes) showing the interquartile range of the simulated changes in each bin. The dashed line is a linear fit (least squares) through the origin to bin median values, $b$ is the slope of the fitted line and the $R$ value is the correlation coefficient. The indicators are (from top to bottom) ensemble mean values of mean annual changes ( $\mathrm{mm}$ ) in precipitation, evapotranspiration, runoff, high runoff, low runoff and snowpack

larger changes for the higher RCP experiment, the differences are generally smaller than those between the warming levels. For example, changes to precipitation increase more between warming levels than between ensembles used to define the $2{ }^{\circ} \mathrm{C}$ warming level. Exceptions are evapotranspiration, snowpack and for all indicators, those grid cells with the largest changes. For evapotranspiration and snowpack, the difference between changes at 1.5 and $2{ }^{\circ} \mathrm{C}$ cannot be discerned from the differences between the high and low emission ensembles for $2{ }^{\circ} \mathrm{C}$.

We also compared the sensitivity of the different HMs to warming (Fig. 2). For 2 vs $1.5^{\circ} \mathrm{C}$, there is less spread in HM response than the magnitude of the projected changes, but for $3 \mathrm{vs}$ $2{ }^{\circ} \mathrm{C}$ the spread is larger than the ensemble mean changes. For the $2{ }^{\circ} \mathrm{C}$ comparison, all models produce similar changes.

The spatial extent and variability of the changes to mean precipitation and evapotranspiration and mean runoff, low runoff, high runoff and snowpack can be seen in Figs. 3 and 4 (also seasonality of runoff in supplementary material online). For all levels of warming, there are robust increases in total annual precipitation in most of central, western and northern Europe. Changes in precipitation are negligible or uncertain in central western and southern Europe and UK, even at the $3{ }^{\circ} \mathrm{C}$ level (Fig. 3). The decreases in precipitation projected around the Iberian coast become larger and more widespread with increasing warming.

For evapotranspiration, there are significant increases projected for Fennoscandinavia and the Alps with smaller, non-robust increases in evapotranspiration in the region between the Netherlands and Ukraine. Differences between the warming levels are harder to discern (also seen in Fig. 1), but evapotranspiration at $3{ }^{\circ} \mathrm{C}$ warming is clearly higher and changes more robust than at $1.5^{\circ} \mathrm{C}$ in most of Europe except the south. Evapotranspiration is projected to decrease on the Iberian Peninsula, and there are clear differences between 3 and $1.5{ }^{\circ} \mathrm{C}$ warming. Evapotranspiration decreases here because although potential evapotranspiration
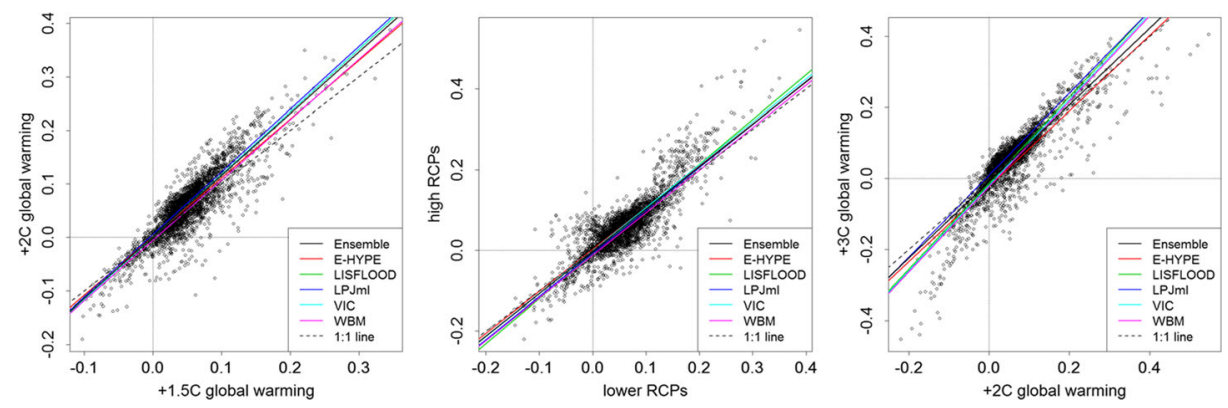

Fig. 2 Comparison of HM sensitivity to warming plotted for different levels of warming (left and right columns) and for different RCPs (middle column) for $+2{ }^{\circ} \mathrm{C}$. The coloured lines are a linear fit (least squares) for each $\mathrm{HM}$ to the $\mathrm{CM}$ ensemble mean changes at each grid point. The points are the HM and CM ensemble mean changes in runoff 


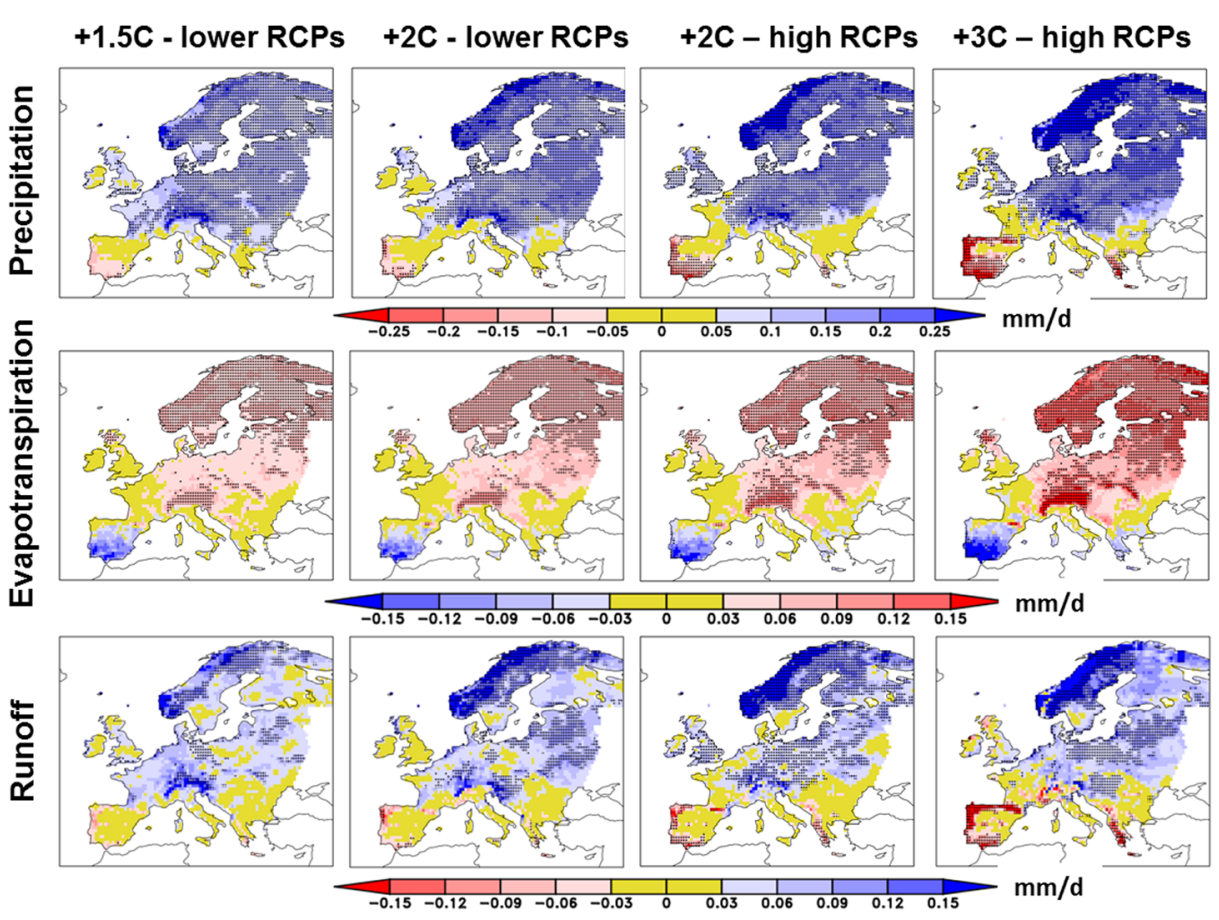

Fig. 3 Ensemble mean changes in 30-year period mean precipitation, evapotranspiration and runoff for $+1.5^{\circ} \mathrm{C}$, $+2{ }^{\circ} \mathrm{C}$ (lower RCPs), $+2{ }^{\circ} \mathrm{C}$ (high RCPs) and $+3{ }^{\circ} \mathrm{C}$. Stippled regions show robust changes

increases with increasing temperatures (e.g. Oudin et al. 2005), less moisture is available for increased actual evapotranspiration due to the decreases in precipitation (Fig. 3).

Changes to runoff in general follow the spatial extent of changes to precipitation but are of a smaller magnitude and less robust (Fig. 3). Increases are robust only for smaller regions, parts of Sweden and Norway, north-eastern Europe, Austria, the northwest Balkans and Hungary (varying between warming levels). However, the extent of these regions increases between the 1.5 and $2{ }^{\circ} \mathrm{C}$ scenarios and between the 2 and $3{ }^{\circ} \mathrm{C}$ scenarios, particularly in northern Europe. Similarly, more widespread and intense decreases in runoff are seen along the Iberian and Balkan coasts as warming level increases. Negligible changes in runoff at all warming levels are seen for large parts of France, UK, Spain, Greece and the Balkans.

For all levels of warming, the changes to runoff are strongest in winter with large increases in runoff seen in Fennoscandinavia and the Alpine regions (Fig. S2 in supplementary material available online). For other seasons, changes are smaller in most parts of Europe, vary in direction and are generally less robust. Nevertheless, there are strong local changes, in particular decreases to spring and summer runoff in Norway and robust increases to spring runoff in the UK. Again, the area affected by changes increases somewhat with increasing warming level as does the intensity and robustness of the signal.

Changes to indicators of snow and low and high runoff are shown in Fig. 4. As expected, the snowpack (annual maximum of snow water equivalent) decreases in most parts of Europe. Nevertheless, there are some local (but non-robust) increases where increases in precipitation in winter outbalance the increases in snowmelt, particularly at $1.5^{\circ} \mathrm{C}$ warming. High runoff levels are set to increase over large parts of continental Europe, increasing in intensity, robustness and spatial extent with increasing warming level. There are localised hotspots for 

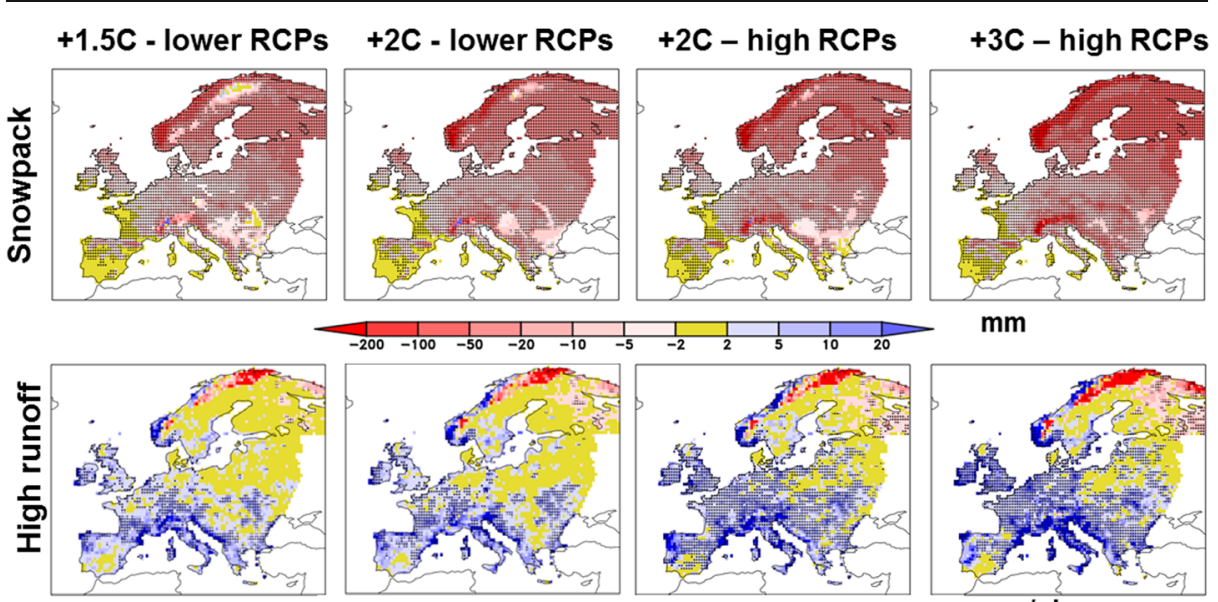

$\mathrm{mm}$
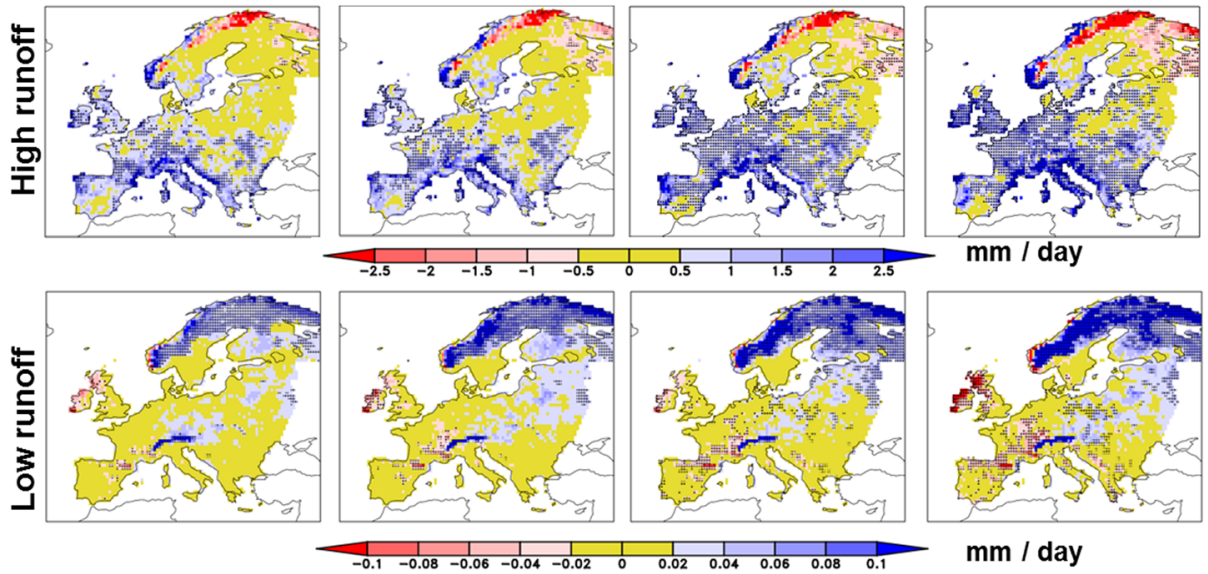

$\mathrm{mm} /$ day

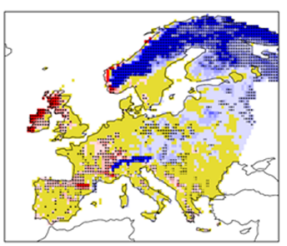

$\mathrm{mm} /$ day

Fig. 4 Ensemble mean changes in 30-year period mean snowpack, low runoff and high runoff indicators for $+1.5^{\circ} \mathrm{C},+2{ }^{\circ} \mathrm{C}$ (lower RCPs), $+2{ }^{\circ} \mathrm{C}$ (high RCPs) and $+3{ }^{\circ} \mathrm{C}$. Stippled regions show robust changes

decreases in low runoff in Western Europe, the UK and Norway. These increase in intensity, robustness and spatial extent with increasing warming. At $3{ }^{\circ} \mathrm{C}$ warming, most of Norway is subject to robust changes in all runoff and snowpack indicators.
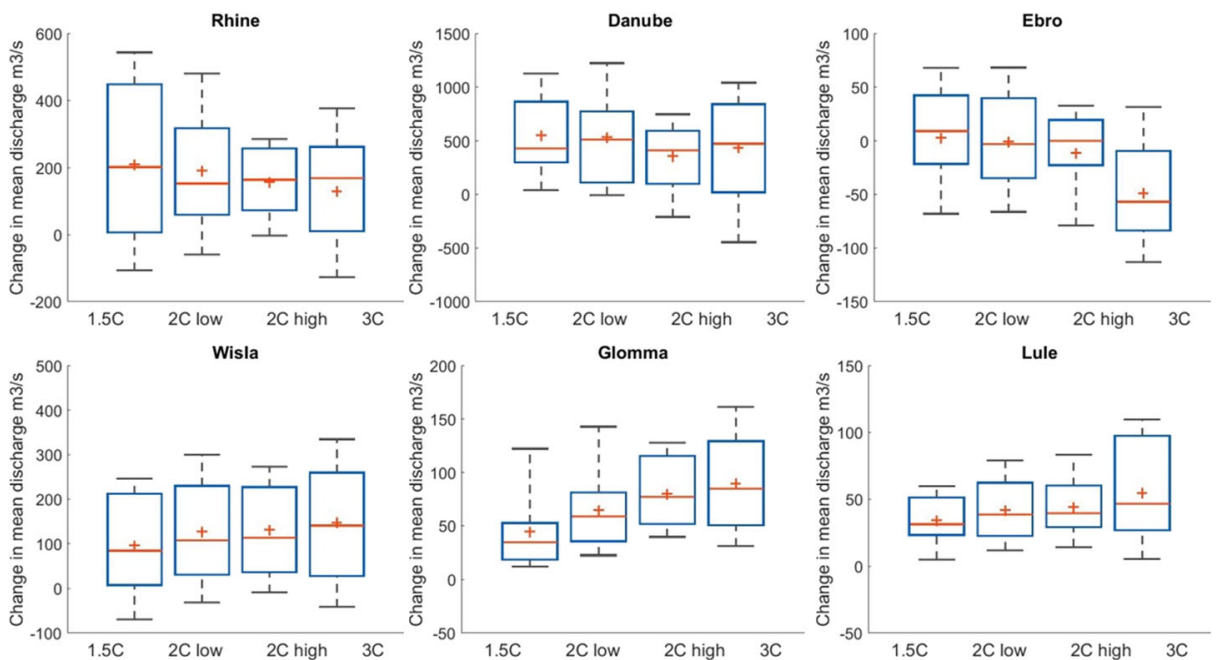

Fig. 5 Box-whisker plots comparing mean discharge changes at $+1.5^{\circ} \mathrm{C},+2{ }^{\circ} \mathrm{C}$ (lower RCPs), $+2{ }^{\circ} \mathrm{C}$ (high RCPs) and $+3{ }^{\circ} \mathrm{C}$ for the rivers Rhine, Danube, Ebro, Wisla, Glomma and Lule 
The variation in mean flow response to the warming levels can be seen for six major European rivers in Fig. 5. Increases to discharge in the Glomma River increase as warming level increases. Similar results, but less robust (large spread compared to changes), are seen for the Wisla and Lule rivers. This is consistent with the increases in mean runoff seen for large parts of northern Europe (Fig. 3). Decreases in river flow with increasing warming level are seen for the Ebro River, consistent with runoff decreases seen in the south. Results for the Rhine and Danube are less clear. Mean increases in river flow in the Rhine at $1.5^{\circ} \mathrm{C}$ warming are larger than at $2{ }^{\circ} \mathrm{C}$ warming but the spread at $1.5^{\circ} \mathrm{C}$ warming is very large compared to the other warming levels. This is partly due to the contrasting changes in winter to summer. In winter, discharges increase due to higher winter precipitation and earlier snowmelt, while summer discharge decreases due to lower snowmelt runoff from the Alps and increased evapotranspiration. However, it is also due to the inhomogeneity of the runoff changes across the river basin. How these processes interact and add up depend on the climate scenario and $\mathrm{HM}$ resulting in a large spread in results and unclear direction of change.

\section{Discussion}

At the regional and continental scale, the results indicated in Fig. 1 support the hypothesis that for most of Europe a higher level of global warming will lead to more severe impacts on precipitation, evapotranspiration, runoff and snow. Impacts increase in severity and spatial extent as warming increases. In particular, our results show a considerable difference between the impacts on mean runoff and low runoff at $1.5^{\circ}$ and $2^{\circ}$ warming indicating the impact that even a small increase in global warming has on European water resources. Similar relationships between hydrological impacts and warming levels have been seen in other studies (e.g. Arnell and Gosling 2016, Gosling et al. 2016, Roudier et al. 2016). Changes to high and low runoff at $2{ }^{\circ} \mathrm{C}$ are similar to those shown for more extreme high and low flows by Roudier et al. (2016); however, the extent of robust changes is smaller in this study, probably because the full HM ensemble was used here. For discharge in large rivers, the link between warming and impact was non-linear and uncertain. These rivers accumulate runoff from large catchment areas over which the changes to runoff were shown to be inhomogeneous (Fig. 3). For example, the Danube accumulates runoff from regions with both robust and non-robust runoff increases and negligible changes to runoff. This result is in contrast with Gosling et al. (2016) which showed more linear trends in impacts for the Rhine River and Tagus which lies close to the Ebro River. In Gosling et al. (2016), a trend-preserving bias-correction method that differs significantly from most quantile methods was used (Hempel et al. 2013). Given that the CMs used were similar and that a large range of regional and global HMs showed similar results, the differences are believed to be caused by the use of this bias-correction methodology.

\section{Uncertainties and limitations}

Uncertainties due to natural variability and the emissions sensitivity of CMs were accounted for by using ensembles of GCM/RCM combinations. While a larger ensemble than the four GCMs used here would have better sampled this uncertainty, there are still insufficient runs available in CORDEX to fully sample these uncertainties (Deser et al. 2012). Furthermore, the 
limited ensemble used here was carefully chosen to sample the spread in possible changes across Europe (Moss et al. 2010). We suggest that future work includes larger ensemble sizes to better account for natural variability.

One limitation in this study is the transient nature of the climates that are assessed from the climate model simulations at different warming levels for only short (30-year) time periods. The advantage of this approach is that analysing an ensemble of projections for different time periods with a common global temperature change removes some of the uncertainty resulting from the GCM's climate sensitivity (Vautard et al. 2014). However, the method relies on the assumption that for a given warming, the impacts of climate change are the same, regardless of the time taken to reach it or whether equilibrium has been reached. One argument against this is that systems, such as the ocean, might take longer to adjust to the $2{ }^{\circ} \mathrm{C}$ period as might changes in biogeochemical processes including changes to evapotranspiration and growth of vegetation at different $\mathrm{CO}_{2}$ concentrations in the atmosphere. To some extent, this is investigated by quantifying the $2{ }^{\circ} \mathrm{C}$ changes using two ensembles forced with different RCPs which reach the $2{ }^{\circ} \mathrm{C}$ warming level at different times (mean midpoint of 2040 vs 2061). The results showed that for the $2{ }^{\circ} \mathrm{C}$ ensembles impact at the same warming level increased with increasing RCP; however, these differences were nearly always smaller than the differences between the different warming levels, supporting the hypothesis that increased warming leads to increased hydrological impacts.

The uncertainty in hydrological response is taken into account using five HMs. The ability of HMs to represent hydrological changes is an important issue that is often neglected in climate change impact assessments and how this should be done is not agreed upon in the scientific community (e.g. Hatterman et al. 2016, Merz et al. 2011). Refsgaard et al. (2013) and Coron et al. (2011) suggest how this could be done for catchment-scale impact modelling but these methods are difficult to implement in continental- or globalscale models. In Greuell et al. (2015), we proposed one index (interannual variability) that gives one indication of how well existing models react to median changes in climate, but acknowledge that this should be supplemented with other analysis and benchmarks. Despite the large variations in HM structure, the spread in HM response for runoff was smaller than the projected changes at lower warming levels, however for higher warming levels $\left(2\right.$ to $3{ }^{\circ} \mathrm{C}$ ), the spread in HM response was larger (Fig. 2) indicating large uncertainties in hydrological response at higher warming. To some extent, using an ensemble of HMs accounts for uncertainties in their responses to change, but there is an urgent need for further work on methods to assess the suitability of large-scale hydrological models for climate change impacts analysis.

The need for bias-correction and choice of bias-correction methodology also introduces uncertainty to the results. The results for the Tagus River by Gosling et al. (2016) using a trend-preserving method were rather different from the nearby Ebro River in this study. Cannon et al. (2015) and Maurer and Pierce (2014) showed that approaches like the quantile mapping used here can change the climate signal in the raw CM output significantly. Nevertheless, it is still unclear which methods give the most realistic climate change projections. Future work might use an ensemble of both trend preservation and bias-adjusting methods until this is decided.

One final limitation is that feedback effects such as the response of vegetation to $\mathrm{CO}_{2}$ and climate changes and anthropogenic influences on landcover and hydrology including adaptation (which could differ at different time points) are not considered. Natural runoff simulations are used in this study; the effects of dam operations and water extractions and transfers both 
historically and in the future are not taken into account. River regulation may affect what impacts changes to future low and high flows will have. Similarly, the impacts due to decreasing mean runoff could be mitigated through better infrastructure. Therefore, this study should only be interpreted as indicative of how climate change affects the natural runoff and not the total water availability or hydrological cycle. Nevertheless, the results can be used together with knowledge of current anthropogenic influences to suggest the implications the changes might have on some sectors if adaptation does not occur.

\section{Implications}

Given the importance of water to so many different sectors, without adaptation, the changes shown here could potentially have large impacts on society and sectors related to water. The decreases in runoff seen along the Mediterranean and Iberian coasts with increasing global warming and the decreases in river flow seen for the Ebro River may affect cooling water availability, agricultural production, reservoir yields for irrigation and water supply in an already water stressed region. The changes to runoff seasonality and low and high runoff affect morphology and ecology. For example, the decreases to outflows from the Ebro River shown here may affect both salt water intrusion upstream as well as the sediment dynamics of the delta (Sánchez-Arcilla et al. 2008). Our results show that mitigating climate change to $1.5{ }^{\circ} \mathrm{C}$ reduces the extent and severity of runoff decreases in southern Europe. Local-scale modelling taking into account the anthropogenic influences would be recommended for this region.

Increases to precipitation and spring runoff (which indicates saturated conditions) in Western Europe may have a detrimental effect on agriculture, for example, when tractors cannot be driven on saturated fields, sowing is delayed which may eventually impact on crop yields (together with many other factors). Decreases in snowpack become more severe at 2 than $1.5^{\circ} \mathrm{C}$ in mountainous regions which will have a negative effect on winter tourism in nearly all snow-dominated regions (Damm et al. 2016). On the positive side, the increases to runoff particularly in Scandinavia and the Alps increase the potential for hydropower electricity generation in the more elevated regions. Seasonally, these regions will get more winter and less spring and summer runoff (due to the snow decreases) which is consistent with the evening out of the annual cycle seen in other studies for snow-dominated regions of Scandinavia (Arheimer and Lindström 2015) and decreases to Spring flood peaks (Roudier et al. 2016). This may decrease the need for reservoir storage of runoff to meet peak winter energy demands. Increases to mean annual runoff and river flow (shown for the Glomma where there is large run-of-the river production capacity) can also lead to increased hydropower generation. The uncertainty of the impacts in large regions of central and Western Europe is of concern because these are intensely cultivated and populated regions. The results presented here could be used in more specific impact models, such as hydropower and agricultural yield models, to help quantify some of these impacts.

\section{Conclusions}

The impacts of climate change on mean, low and high runoff and mean snowpack in Europe increase with increased warming level. Changes to runoff are more intense at 2 than $1.5^{\circ} \mathrm{C}$ and 
become more widespread at $3{ }^{\circ} \mathrm{C}$. The fact that the hydrological impacts of climate change are geographically more widespread for higher levels of warming implies that larger regions and more countries will be impacted by the effects of climate change in sectors where water plays an important role. The projected impacts are sensitive to the choice of RCP in the ensemble to represent the warming level, but this effect is less than the effect of the different warming levels. We therefore conclude that warming levels affect hydrological impacts, but point out that there remain uncertainties in the magnitudes and locations of changes. Finally, the results shown here indicate that it does make a difference on water impacts in Europe if we can mitigate global warming to $1.5{ }^{\circ} \mathrm{C}$. Given the current emissions trajectory beyond a $+3{ }^{\circ} \mathrm{C}$ warming, substantial emissions reductions will be required to avoid severe impacts on the water cycle in Europe.

Acknowledgements The research leading to these results has received funding from the European Union Seventh Framework Programme (FP7/2007-2013) under the project: IMPACT2C: Quantifying projected impacts under $2{ }^{\circ} \mathrm{C}$ warming, grant agreement no. 282746. We are grateful for use of the regional downscaling and bias-correction done within that project.

Open Access This article is distributed under the terms of the Creative Commons Attribution 4.0 International License (http:/creativecommons.org/licenses/by/4.0/), which permits unrestricted use, distribution, and reproduction in any medium, provided you give appropriate credit to the original author(s) and the source, provide a link to the Creative Commons license, and indicate if changes were made.

\section{References}

Arheimer B, Lindström G (2015) Climate impact on floods: changes in high flows in Sweden in the past and the future (1911-2100). Hydrol Earth Syst Sci 19:771-784. doi:10.5194/hess-19-771-2015

Arnell NW, Gosling SN (2016) The impacts of climate change on river flood risk at the global scale. Clim Chang 134(3):387-401

Biemans $\mathrm{H}$ et al (2009) Impacts of precipitation uncertainty on discharge calculations for main river basins. J Hydrometeorol 10:1011-1025

Burek P, van der Knijff J, de Roo A (2013) LISFLOOD distributed water balance and flood simulation model. Revised user manual. JRC technical reports EUR $22166 \mathrm{EN} / 3 \mathrm{EN}$

Cannon AJ, Sobie SR, Murdock TQ (2015) Bias correction of GCM precipitation by quantile mapping: how well do methods preserve changes in quantiles and extremes? J Clim 28(17):6938-6959

Coron L, Andréassian V, Bourqui M, Perrin C, Hendrickx F (2011) Pathologies of hydrological models used in changing climatic conditions: a review. Hydro-Climatology: Variability and Change IAHS Publication 344 : 39-44

Damm A, Greuell W, Landgren O, Prettenthaler F (2016) Impacts of $+2{ }^{\circ} \mathrm{C}$ global warming on winter tourism demand in Europe. Climate Services. doi:10.1016/j.cliser.2016.07.003

Deser C et al (2012) Uncertainty in climate change projections: the role of internal variability. Clim Dyn 38:527546

Donnelly C, Andersson JCM, Arheimer B (2016) Using flow signatures and catchment similarities to evaluate the E-HYPE multi-basin model across Europe. Hydrol Sci J. doi:10.1080 /02626667.2015.1027710

Forzieri G et al (2014) Ensemble projections of future streamflow droughts in Europe. Hydrol Earth Syst Sci 18(1):85-108

Gosling SN et al (2016) A comparison of changes in river runoff from multiple global and catchment-scale hydrological models under global warming scenarios of $1{ }^{\circ} \mathrm{C}, 2^{\circ} \mathrm{C}$ and $3^{\circ} \mathrm{C}$. Clim Chang. doi:10.1007 /s10584-016-1773-3

Greuell W et al (2015) Evaluation of five hydrological models across Europe and their suitability for making projections under of climate change. Hydrol Earth Syst Sci Discuss 12:10289-10330. doi:10.5194/hessd-1210289-2015 
Hatterman et al (2016) Cross-scale intercomparison of climate change impacts simulated by regional and global hydrological models in eleven large river basins. Climatic Change (in press). doi:10.1007/s10584-016-18294

Haylock MR et al (2008) A European daily high-resolution gridded data set of surface temperature and precipitation for 1950-2006. J Geophys Res Atmos 113. doi:10.1029/2008jd010201

Heinke J et al (2013) A new dataset for systematic assessments of climate change impacts as a function of global warming. Geosci Model Dev 6:1689-1703

Hempel S et al (2013) A trend-preserving bias correction - the ISI-MIP approach. Earth Sys Dyn 4(2):219-236

Jacob D et al (2014) EURO-CORDEX: new high-resolution climate change projections for European impact research. Reg Environ Chang 14:563-578. doi:10.1007/s10113-013-0499-2

Jiménez Cisneros B E et al (2014) Freshwater resources. In: Field CB, et al. (eds.) Climate Change 2014: impacts, adaptation, and vulnerability. Part A: global and sectoral aspects. Contribution of Working Group II to the Fifth Assessment Report of the Intergovernmental Panel on Climate Change. Cambridge University Press, Cambridge, United Kingdom and New York, pp. 229-269

Liang X, Lettenmaier DP, Wood EF, Burges SJ (1994) A simple hydrologically based model of land surface water and energy fluxes for general circulation models. J Geophys Res Atmos 99(19842012):14415-14428

Maurer EP, Pierce DW (2014) Bias correction can modify climate model simulated precipitation changes without adverse effect on the ensemble mean. Hydrol Earth Syst Sci 18(3):915-925

Meehl GA, et al (2007) Global climate projections. In: Solomon SD, et al (eds.). Climate Change 2007: the physical science basis. Contribution of Working Group I to the Fourth Assessment Report of the Intergovernmental Panel on Climate Change. Cambridge University Press, Cambridge and New York

Merz R, Parajka J, Blöschl G (2011) Time stability of catchment model parameters: implications for climate impact analyses. Water Resources Research 47(2)

Moss RH et al (2010) The next generation of scenarios for climate change research and assessment. Nature 463: $747-747$

Nijssen B, O'Donnell GM, Lettenmaier DP, Lohmann D, Wood EF (2001) Predicting the discharge of global rivers. J Clim 14:3307-3323

Oudin L, Michel C, Anctil F (2005) Which potential evapotranspiration input for a lumped rainfall-runoff model?: part 1-can rainfall-runoff models effectively handle detailed potential evapotranspiration inputs? J Hydrol 303(1):275-289

Refsgaard JC et al (2013) A framework for testing the ability of models to project climate change and its impacts. Clim Chang 122(1-2):271-282

Roudier P et al (2016) Projections of future floods and hydrological droughts in Europe under a+ $2{ }^{\circ} \mathrm{C}$ global warming. Clim Chang 135(2):341-355

Sánchez-Arcilla A, Jiménez JA, Valdemoro HI, Gracia V (2008) Implications of climatic change on Spanish Mediterranean low-lying coasts: the Ebro Delta case. J Coast Res 24(2):306-316

Sanford T, Frumhoff PC, Luers A, Gulledge J (2014) The climate policy narrative for a dangerously warming world. Nat Clim Chang 4(2014):164-166. doi:10.1038/nclimate2148

Schaphoff S et al (2013) Contribution of permafrost soils to the global carbon budget. Environ Res Lett 8: 014026,5. doi:10.1088/1748-9326/8/1/014026

Schneider C, Laizé CLR, Acreman MC, Florke M (2013) How will climate change modify river flow regimes in Europe? Hydrol Earth Syst Sci 17(1):325-339

Taylor KE, Stouffer RJ, Meehl GA (2012) An overview of CMIP5 and the experiment design. Bull Met Am Soc 93:485-498. doi:10.1175/BAMS-D-11-00094.1

UNFCCC (2010) Report of the Conference of the Parties on its sixteenth session, held in Cancun from 29 November to 10 December 2010. Available from http://unfccc.int/resource/docs/2010/cop16/eng/07a01.pdf. United Nations, Geneva

UNFCCC (2015) Adoption of the Paris Agreement. Proposal by the President. Proposal by the President. Available from: http://unfccc.int/resource/d ${ }^{\circ} \mathrm{Cs} / 2015 /$ cop21/eng/109r01.pdf. United Nations, Geneva

Van Vliet M, Donnelly C, Stromback L, Capell R (2015) European scale climate information services for water use sectors. J Hydrol 528:503-513

Vautard R et al (2014) The European climate under a $2^{\circ} \mathrm{C}$ global warming. Environ Res Lett 9:034006

Vörösmarty CJ, Green P, Salisbury J, Lammers RB (2000) Global water resources: vulnerability from climate change and population growth. Science 289(5477):284-288

Weedon GP et al (2014) The WFDEI meteorological forcing data set: WATCH forcing data methodology applied to ERA-interim reanalysis data. Water Resour Res 50(9):7505-7514

Wilcke R, Mendlik T, Gobiet A (2013) Multi-variable error correction of regional climate models. Clim Chang 120:871-887. doi:10.1007/s10584-013-0845-X 